\title{
1994年国際肝臓研究会印象記
}

\section{浪久 利彦}

国際肝臓研究会は 5 月19日より23日までメキシコのカンクーンで開催され，19および20日 は卒後教育講演が行われ，学会は21日より開催された。初日は朝 8 時から Camino Real Hotelにおいて Leevy 教授が chairman, Tygstrup 教授が co-chairman となり, Satellite Symposium : Prognosis of Alcoholic Liver Diseases and Hepatitis C : Problems, Methods and Results.が開催された. 肝蔵学の進歩, 診断基準の改変などにより新しい展開が期待され ることからこのシンポジウムが持たれたものであり, Maddrey 教授はアルコール性肝障害の 組織所見についての彼の新しい分類法が各種治療法の評価や肝移植の適応に意義があること を発表し, Mandenhall 教授はアルコール性肝障害の新しい治療法の導入について述べ, Christensen 教授は研究成績の評価に対する統計学的手法の重要性を述べた. Seeff 教授, Poynard 教授, Schalm 教授およびAndersen 教授からC 型肝炎の予後因子についての発表 があったが，わが国の広範な成績を無視してこの問題を討議することは妥当でないと考えら れた.

11時30分からは主会場である American Fiesta Coral Beach Hotelにおいて Manns 教授 によりDame Sheila Sherlock State of The Art Lecture. Auto-antibodies In Liver Diseases: Diagnostic Reagents and Scientific Tools. が講演された. 各種肝疾患における 自己抗体およびその対応抗原について最新の手技を用いた検索法を述べ,さらにそれと病因 との関連を考察され，示唆に富んだ講演であった。

16時30分からは Chojkier 教授より State of The Art Lecture: What Makes A Liver A Liver : Molecular Mechanism. が講演された. 肝臓が肝蔵として特異性を示すのは肝細胞が アルブミンなどの特異蛋白を合成分泌することで，その遺伝子の発現が新しい意味での肝臓 の特異性であるとの内容で，かなり難解であったが将来の方向性を示すものとして注目され た.

22日は主としてポスターおよびポスター講演が行われたが，わが国からも多数の発表がな された. 18時からはArias教授により State of Art Lecture: Adventures In The Bile Canaliculus. が講演された. 各種の物質が肝細胞質から毛細胆管に排泄される機序について, 特に形質膜 P-Glycoprotein を中心とした移送について, 正常のみでなく胆汁うっ滞時におけ る変化まで言及され，興味深い講演であった。

23日は最終日で盛り沢山の講演があった. 8 時より Debate: Should Hepatology Be A Separate Clinical Dicipline? と題して R. Schmid 教授が chairman, McIntyre 教授が cochairman となり，各国の事情が述べられた. McIntyre 教授は英国においては肝臓学は消化 
器病学の一部門として内科学と緊密な連携をとりながら専門分科として存在しており, 多数 の肝臓專門医は必要でないが，大病院において肝臓部門は絶対に必要であるとした。カナダ では肝㵴専門医は約40名で, 肝蔵センターは大規模のものが 2 力所, 小規模のものが十数力 所あり，患者数からみれば少ないとは言えないが， academic staff としては絶対に必要であ ると結論した. Powell 教授はオーストラリアの現状について, 実態はカナダとほほ同様であ るとした. Sorrel 教授は米国の現状を踏まえてより具体的な提案をされ，消化器専門医の研 修期間が 3 年である場合は 1 年間， 2 年である場合はさらに 1 年間肝臟学の研修を行うべき であり，このためにはそれに見合う肝臓專門医制が必要であるとしたが，現実の問題として 肝臓専門医は経済的には独立し得ず，消化器専門医の資格を同時に保持すべきとした。さら に 7 名の教授から各国の現状について報告があり，わが国については小俣教授より独特な現 状についての紹介があった. Schalm 教授はオランダの現状について述べ, 専門医は約30名お り,これによって臨床的にはほぼ満足されているが,その活用と教育のためには肝臓センター が必要であるとされた. Manns 教授はドイツにおける現状から消化器病学とバランスをとっ て内科における 1 単位として存在することが必要と述べた. 最後に Sherlock 教授から,この 問題は地域の特殊性が重要で, 肝疾患の多発している地域では専門医を多数必要とし, 肝疾 患の少ない地域でも academic staff として必ず確保せねばならないと結論された. 以上の発 表後会場から質問およびコメントが相次ぎ，最後に，1）肝蔵学は独立した分科としては存在 すべきでない，2）肝臟学は完全な分科として存在すべきである，3）肝㵴学は消化器科の一 分科として存在すべきである，との 3 項目について挙手で賛否が問われ，2）と3)がほぼ同数 を占めた.この結果は現在の肝臟学の実態と問題点を示すものと考えられた.

11時30分より State of The Art Lecture: Hepatis C Virus and C Disease. が小俣教授に より講演され，わが国の幅広い研究に聴衆は深い感銘を受けたように見られた. 12時からは Hans Popper State of The Lecture: Vesicle Transport: What The Traffic will Bear? が Boyer 教授によって講演され，肝細胞質における vesicleの移送には種々の蛋白質あるい は細胞骨格が関与することを示し, 機能と構造の面からの詳細な報告がなされた。

2 時からはTiribelli 教授により IASL Cooperative Study on Hepatocellular Carcinoma. が報告された. AASL, APASL, LAASL, AFASL, EASL 各地域の集計結果が 報告され, HCC の動向を占う意味で継続的な観察が要望された。

3 時30分から Workshop: Morphological Aspect And Classification of Chronic Hepatitis. が開催され, Chairman の Desmet 教授より慢性肝炎の分類に関する歴史的な変遷につい て述へられ，各種肝炎ウイルスの発見や新しい治療法の開発によりこの分類法が使用困難と なり，今回の検討が行われたとの経緯が報告された．今回の分類ではまずその成因によりウ イルス性, 自己免疫性, 薬物性および原因不明の 4 種類に分け, $\alpha_{1}$-antitrypsin 欠損症, Wilson 病, PBC, PSC は除外された. 第 2 段階としては staging と grading に分け, staging は疾患 の予後を示し, gradingは疾患の活動性をしめす指標としている。これに続いて病理側 2 名, 
臨床側 2 名によるコメントが述べられ, Hoofnagel 教授は grading と staging に点数を配分 して計量化を計り, Manns 教授は組織学的変化のみでなく臨床検查成績の重要性を指摘され た. 病理側から Scheuer 教授及び Gerber 教授が発言され, grading は necroinflammatory activityを表すものであり， staging には線維化が重要であると述べられた。これに続いて American Association of Gastroenterologyにおいて慢性肝炎の分類を担当されている Ludwig 教授よりコメントがあり，これらの提案は近々Hepatology あるいは Gastroenterology 揭載される予定であることが述べられたが, 実施にはなる検討の余地があるものと考え られた。

17時からは Rojkind 教授により Special Lecture : Liver Fibrosis : Past and Future. が講 演されたが, 同教授はメキシコのお生まれで，故郷に錦を飾ったものと拝見された，以上で 学術講演はすべて終わり，17時30分より Rodes 会長より Closing Remarks が述べられた. 次回は Terblance 教授のもとで1996年 2 月に南アフリカ共和国の Cape Town で開催さ れることが決定発表された。

このレポートは小生が直接参加した講演のみに限って紹介したが，これ以外にも優れた発 表が多数あり，紹介し得なかったのが残念である.（1994年 5 月24日記）

(順天堂大学名誉教授) 